\title{
Modification of Cell Wall Polysaccharides during Drying Process Affects Texture Properties of Apple Chips
}

\author{
Min Xiao, ${ }^{1}$ Jianyong Yi $\mathbb{D},{ }^{1}$ Jinfeng Bi $\mathbb{D},{ }^{1}$ Yuanyuan Zhao, ${ }^{1}$ Jian Peng, \\ Chunhui Hou, ${ }^{1,2}$ Jian Lyu, ${ }^{1}$ and Mo Zhou ${ }^{1}$ \\ ${ }^{1}$ Institute of Food Science and Technology, Chinese Academy of Agricultural Science (CAAS), Key Laboratory of \\ Agro-Products Processing, Ministry of Agriculture, Beijing 100193, China \\ ${ }^{2}$ College of Food Engineering and Biotechnology, Tianjin University of Science \& Technology, Tianjin 300457, China
}

Correspondence should be addressed to Jianyong Yi; yijianyong_caas@yeah.net and Jinfeng Bi; bjfcaas@126.com

Received 28 October 2017; Accepted 5 February 2018; Published 29 March 2018

Academic Editor: Chung-Lim Law

Copyright (c) 2018 Min Xiao et al. This is an open access article distributed under the Creative Commons Attribution License, which permits unrestricted use, distribution, and reproduction in any medium, provided the original work is properly cited.

\begin{abstract}
The influences of hot air drying (AD), medium- and short-wave infrared drying (IR), instant controlled pressure drop drying (DIC), and vacuum freeze drying (FD) on cell wall polysaccharide modification were studied, and the relationship between the modifications and texture properties was analyzed. The results showed that the DIC treated apple chips exhibited the highest crispness (92) and excellent honeycomb-like structure among all the dried samples, whereas the FD dried apple chips had low crispness $(10)$, the minimum hardness $(17.4 \mathrm{~N})$, and the highest volume ratio (0.76) and rehydration ratio (7.55). Remarkable decreases in the contents of total galacturonic acid and the amounts of water extractable pectin (WEP) were found in all the dried apple chips as compared with the fresh materials. The highest retention of WEP fraction (102.7 mg/g AIR) was observed in the FD dried apple chips, which may lead to a low structural rigidity and may be partially responsible for the lower hardness of the FD apple chips. In addition, the crispness of the apple chips obtained by DIC treatment, as well as AD and IR at $90^{\circ} \mathrm{C}$, was higher than that of the samples obtained from the other drying processes, which might be due to the severe degradation of pectic polysaccharides, considering the results of the amounts of pectic fractions, the molar mass distribution, and concentrations of the WEP fractions. Overall, the data suggested that the modifications of pectic polysaccharides of apple chips, including the amount of the pectic fractions and their structural characteristics and the extent of degradation, significantly affect the texture of apple chips.
\end{abstract}

\section{Introduction}

Apple, one of the most cultivated and consumed fruits in China, is a significant part of the human diet. It has been identified as one of the main dietary sources of food antioxidants, mainly due to the phenolic compounds such as flavonoids and phenolic acids. These functional substances may contribute to the nutritional effects; for example, they could reduce risk of cancer, heart disease, and asthma [1]. From the health benefit point of view, a variety of technologies have been applied to develop different types of apple products, including apple juices, purees, and apple chips.

Since drying has been used as an effective method to process apples, a large number of studies have been focused on the qualities of dehydrated apple, such as color, flavor, taste, and texture, as well as nutrition and functionality.
Among these quality aspects, texture is one of the vital organoleptic properties which is closely related to consumer acceptability. Complex physicochemical and biological reactions occur during drying process which could greatly affect the microstructure and texture of material tissues. To be specific, the volume of a material would decline continuously due to the loss of osmotic pressure caused by the evaporation of inner moisture. Additionally, the shrinkage of tissues is also related to the loss of vacuolar pressure and further damage to the integrity of cell wall, thus resulting in textural changes that could play an important role in the quality of dried fruit and vegetable products [2]. Generally, it is recognized that the microstructure and porosity of materials are the most important properties of dried food that affect its texture. Therefore, there are great interests in the development of methods to predict and control the texture of plant-based foods during 
drying. The correlation between textural properties and the microstructure has also been the subject of many research efforts [3-5].

Texture is the result of complex interaction among food components relating to molecular, supramolecular, and the microstructural levels [6]. Plant cell wall and the middle lamella are known to control the way in which plant tissues undergo mechanical deformation and failure during mastication $[7,8]$. The plant cell wall is made up of complex polysaccharides, phenolic compounds, and proteins stabilized by covalent and noncovalent (e.g., ionic) linkages. The cell wall of apples is generally depicted as a pectin-rich structure, containing high amounts of rhamnose [9]. Pectin is a complex polysaccharide which generally consists of three domains, that is, homogalacturonan (HG) (smooth region), rhamnogalacturonan-I (RG-I), and rhamnogalacturonan-II (RG-II) (hairy regions) [10]. The evolution of texture occurs during the processing of plant materials or some physiological events, which are related to the increased solubility of cell wall polysaccharides and the microstructure changes, such as the loss of the integrity in cell wall and middle lamella, changes on cell adhesion, and structural changes on pectin fraction.

Recently, the structural changes on cell wall polysaccharides during drying have also been reported for several fruits. The rehydration property of air-dried broccoli substantially affected by the amount and structure of cell wall pectin polysaccharides was reported [11]. Latorre et al. [12] claimed that microwave treatment modified the structure of cell wall polysaccharides in such a manner that produced an increase in their hydrophilicity. Yi et al. [13] studied the relationship between the modification in composition, structure, and extractability of cell wall polysaccharides and the alteration in volume expansion, microstructure, $T_{g}$, and rehydration behaviors, confirming that cell wall polysaccharide played a significant role in the physicochemical and physical properties of pitaya fruit chips. During sun-drying process, the molecular size distribution of water extractable pectin was affected by the degradation of arabinogalactan and arabinan side chains [14]. However, the impact of structural modification of cell wall polysaccharides on the texture of dehydrated fruits and vegetables is still obscure. A better understanding of the biochemical changes occurring during drying, and how these changes are related to texture variation, is expected to lead ultimately to a better process control and final product quality, valorisation, and acceptance.

The objective of this study was to investigate the effects of four different drying methods on the characteristics of cell wall polysaccharides of apple chips and to study the relationship between cell wall polysaccharides and texture of apple chips.

\section{Materials and Methods}

2.1. Sample Preparation. Apples (Malus pumila Mill var. Qin) were bought from the Xiaoying market in Beijing. Moisture content of fresh apple was $7.0 \pm 0.3 \mathrm{~kg} / \mathrm{kg}$ d.b. The peel was removed from the apples and they were cut into slices with $10 \mathrm{~mm}$ thickness and $20 \mathrm{~mm}$ diameter uniformly.

\subsection{Methods}

2.2.1. Drying Methods. Hot air drying (AD) was carried out using a convective dryer (DHG-9203, Yiheng Technical Co. Ltd., Shanghai, China). The dryer was loaded with $750 \mathrm{~g}$ $\left(6.79 \mathrm{~kg} / \mathrm{m}^{2}\right)$ of apple slices that were spread on a tray in single layer. The samples were flipped over during drying to avoid sticking to the tray and allow equal dehydration from all sides. Fresh apple slices were dried at $60^{\circ} \mathrm{C}, 75^{\circ} \mathrm{C}$, and $90^{\circ} \mathrm{C}$, respectively.

Infrared drying (IR) was operated using a laboratory medium- and short-wave infrared dryer (STC-5, Senttech Infrared Technology Co. Ltd., Jiangsu, China). The dryer consists of three infrared lights with powers of $0.48,0.60$, and $0.90 \mathrm{~kW}$ and wavelengths of $3.15,3.10$, and $1.40 \mu \mathrm{m}$, respectively. The samples were dried at $60^{\circ} \mathrm{C}, 75^{\circ} \mathrm{C}$, and $90^{\circ} \mathrm{C}$, respectively. The power density of IR process was $1.8 \mathrm{KW} / \mathrm{kg}$, the air velocity was $2.11 \mathrm{~m} / \mathrm{s}$, and the distance from the emitters to the sample tray was $12 \mathrm{~cm}$. For AD and IR drying, the moisture at equilibrium was measured when the weight of samples became constant. In this study, the drying times were $450 \mathrm{~min}, 300 \mathrm{~min}$, and $250 \mathrm{~min}$ for $\mathrm{AD}$ at 60 , 75, and $90^{\circ} \mathrm{C}$, respectively, and 200,120, and $100 \mathrm{~min}$ for IR at 60, 75, and $90^{\circ} \mathrm{C}$, respectively.

Freeze drying (FD) was conducted using an experimental freezing dryer (Alphal-4L plus, Christ Col, Osterode am Harz, German) with a drying area of $0.42 \mathrm{~m}^{2}$. Before freeze drying, the apple samples were prefrozen at $-80^{\circ} \mathrm{C}$ for $12 \mathrm{~h}$ and then freeze-dried for $15 \mathrm{~h} \mathrm{[16]}$. The pressure was around 0.12 mbar with the condenser temperature of $-56^{\circ} \mathrm{C}$. The heating plate temperature was $35^{\circ} \mathrm{C}$.

Instant controlled pressure drop (French: Détente Instantannée Contrôlée, DIC), also known as explosion puffing drying (EPD), was developed since 1988 [17, 18]. Prior to DIC treatment, samples were predried by $\mathrm{AD}$ at the same condition as the abovementioned AD drying. Apple chips were predried to the moisture content of $0.3 \mathrm{~kg} / \mathrm{kg}$ w.b. by hot air drying at $70^{\circ} \mathrm{C}$. After predrying, the samples were tightly wrapped in polyethylene bags and equilibrated in a thermostatic chamber at $20^{\circ} \mathrm{C}$ for $24 \mathrm{~h}$. The above equilibrated semidried samples were removed to an experimental DIC dryer (QDPH10-1, Tianjin Qin-de New Material Scientific Development Co. Ltd., Tianjin, China), which was depicted in a previous study [13]. Prior to DIC treatment, the samples were equilibrated at $90^{\circ} \mathrm{C}$ for $10 \mathrm{~min}$ under the atmospheric pressure. Meanwhile, the vacuum tank was evacuated to approximate $3 \mathrm{kPa}$, producing enough vapor pressure, thus contributing to the expansion of the apple slices during the next stages of DIC drying. Then, the snuffle valves were opened to obtain an abrupt pressure drop to vacuum (around $3 \mathrm{kPa}$ ) in the treatment chamber, namely, instant pressure drop. Then, the apple slices were dried under a continuous vacuum at $65^{\circ} \mathrm{C}$ for $2 \mathrm{~h}$. Each drying process was performed in triplicate.

2.2.2. Moisture Content. Moisture content was determined by drying the samples at $105^{\circ} \mathrm{C}$ until reaching constant weight [19]. 
2.2.3. Texture Analysis. The hardness and crispness of apple chips were measured by a TA-XT2i/50 Texture Analyzer (Stable Micro Systems Ltd., Surry, UK). A cylinder penetrometer probe ( $5 \mathrm{~mm}$ diameter) was used and the test parameters were set as follows: $2 \mathrm{~mm} / \mathrm{s}$ of the prespeed and postspeed, $1 \mathrm{~mm} / \mathrm{s}$ of the test speed, and $100 \mathrm{~g}$ trigger. In the test, hardness is the maximum force required to break the sample [17] and the crispness is characterized by the number of peaks [20]. Twelve measurements were performed for each treatment.

2.2.4. Volume Ratio (VR) and Rehydration Ratio (RR). The VR was measured using quartz sand displacement method [21]. VR was evaluated as volume change of apple cylinders affected by drying methods. The VR of dried apple chips can be determined by

$$
\mathrm{VR}=\frac{V_{m}}{V_{0}},
$$

where $V_{0}$ and $V_{m}$ are the initial and dried sample volumes, respectively.

The RR of dried products is one of important indications for the occurrence of physical and chemical changes during drying process due to drying conditions, pretreatment, and sample composition [22]. Five grams of dried samples was put in $50 \mathrm{~mL}$ distilled water in $250 \mathrm{~mL}$ beaker. Samples were taken out after $2 \mathrm{~h}$ and filter papers were used to wipe the excess water on the surface of the samples. The weights of the samples were recorded before and after rehydration. The RR was calculated according to

$$
\mathrm{RR}=\frac{m_{r}}{m_{0}},
$$

where $m_{0}$ and $m_{r}$ are the initial and dried sample weights, respectively.

2.2.5. Scanning Electron Microscopy (SEM). Microstructure characterization was performed using a scanning electron microscope (SEM S-570, Hitachi Ltd., Tokyo, Japan) at $150 \mathrm{kV}$ accelerated voltage and $10-15 \mathrm{~mm}$ working distance. The microstructure of the samples was magnified 50 times.

2.2.6. Extraction of Cell Wall Polysaccharides and Fractionation. The cell wall polysaccharides of dried apple slices, namely, alcohol insoluble residue (AIR), were prepared following the procedure described by Gwanpua et al. [23]. About $30 \mathrm{~g}$ of dried apple chips was weighed and homogenized in $180 \mathrm{~mL}$ of $95 \%$ ethanol using a mixer (Joyoung Co. Ltd., Shandong, China). The residue was filtered and resuspended in $90 \mathrm{~mL}$ of $95 \%$ ethanol. The insoluble cell wall fraction was washed with $90 \mathrm{~mL}$ of acetone and filtered. To obtain AIR, the suspension was dried at $40^{\circ} \mathrm{C}$ for $36 \mathrm{~h}$. AIR fractionation was performed according the procedure of Christiaens et al. [24]. For water extractable pectin (WEP), $1.0 \mathrm{~g}$ AIR samples were weighed exactly and suspended in $180 \mathrm{ml}$ boiling water for $5 \mathrm{~min}$. The solution was cooled and filtered using a filter paper (Machery-Nagel, MN615, $90 \mathrm{~mm}$ ) and then adjusted to $200 \mathrm{~mL}$ with distilled water. The residue was further fractionated in $180 \mathrm{~mL}, 0.05 \mathrm{~mol} / \mathrm{L}$ cyclohexane-trans-1,2diamine tetraacetic acid (CDTA) in $0.1 \mathrm{~mol} / \mathrm{L}$ potassium acetate (PH 6.5) for $6 \mathrm{~h}$ at $28^{\circ} \mathrm{C}$ in a shaking water bath. The solution was adjusted to $200 \mathrm{~mL}$ with distilled water, which was labeled as CDTA extractable pectin (CEP). The residue was sequentially incubated in $180 \mathrm{~mL} 0.05 \mathrm{~mol} / \mathrm{L} \mathrm{Na}_{2} \mathrm{CO}_{3}$ containing $0.02 \mathrm{~mol} / \mathrm{L} \mathrm{NaBH}_{4}$ and stirred for $16 \mathrm{~h}$ at $4{ }^{\circ} \mathrm{C}$. The solution was filtered and the filtrate was adjusted to $200 \mathrm{~mL}$. The filtration of the suspension was designated as $\mathrm{Na}_{2} \mathrm{CO}_{3}$ extractable pectin (NEP). All extracts were filtered, dialyzed exhaustively in distilled water, and finally lyophilized [25]. The samples were stored in a desiccator over $\mathrm{P}_{2} \mathrm{O}_{5}$.

2.2.7. Galacturonic Acid (GalA) Content. The AIRs and the corresponding fractions obtained thereof (WEP, CEP, and NEP) were first hydrolyzed using concentrated sulfuric acid (95-98\%) according to the method described by Ahmed and Labavitch [26]. GalA contents of the hydrolyzates were measured by a colorimetric hydroxyl-phenyl-phenol method using a UV/Vis spectrophotometer (UV1800, Shimadzu, Kyoto, Japan) at $520 \mathrm{~nm}$, according to the procedure by Blumenkrantz and Asboe-Hansen [27]. The GalA content measurement was conducted in triplicate.

2.2.8. Degree of Methoxylation (DM). The DM of the fractions of the AIR fractions were calculated as the ratio of the molar amount of methoxy groups to the molar amount of GalA content and expressed as a percentage. Before the measurement of the concentration of methanol, $20 \mathrm{mg}$ of each dried AIR faction was weighed and was first hydrolyzed according to the description of $\mathrm{Ng}$ and Waldron [28]. The amount of methanol was spectrophotometrically determined by the method of Klavons and Bennett [29]. Determination of DM was conducted in triplicate.

2.2.9. Neutral Sugar Composition. Analyses of neutral sugars including fucose (Fuc), rhamnose (Rha), arabinose (Ara), galactose (Gal), and xylose (Xyl) were performed using the method described by Njoroge et al. [30]. Five grams of lyophilized AIR fractions (i.e., WEP, CEP, and NEP) was hydrolyzed with $0.5 \mathrm{~mL} 4 \mathrm{~mol} / \mathrm{L}$ trifluoroacetic acid for $1.5 \mathrm{~h}$ at $110^{\circ} \mathrm{C}$. After cooling and evaporation of the trifluoroacetic acid, samples were diluted with demineralized water to a concentration of $1 \mathrm{mg} / \mathrm{mL}$. Quantification of the neutral sugars of the fractions was performed via high-performance anion exchange chromatography (HPAEC) using a Dionex Bio-LC System including a quaternary gradient pump (Dionex BioLC System, Dionex Co., Sunnyvale, CA, USA). An $\mathrm{ED}_{50}$ electrochemical detector equipped with a gold electrode was used in the pulsed amperometric detection mode, performing a quadruple potential waveform. After equilibration of the system for $5 \mathrm{~min}$ with $100 \mathrm{mmol} / \mathrm{L} \mathrm{NaOH}$ and $5 \mathrm{~min}$ with $4 \mathrm{mmol} / \mathrm{L} \mathrm{NaOH}$, the diluted hydrolyzate $(10 \mu \mathrm{L})$ was eluted at $30^{\circ} \mathrm{C}$ on a CarboPac PA20 column (Dionex) with $4 \mathrm{mmol} / \mathrm{L} \mathrm{NaOH}$ at a flow rate of $0.5 \mathrm{~mL} / \mathrm{min}$. Thereafter, column wash was performed for $10 \mathrm{~min}$ with $500 \mathrm{mmol} / \mathrm{L}$ $\mathrm{NaOH}$. Commercial neutral sugar standards were used for identification and quantification. Correction for degradation of monosaccharide during acid hydrolysis was performed 
TABLE 1: Moisture content, hardness, crispness, volume ratio, and rehydration ratio of the dried apple chips obtained by different drying methods.

\begin{tabular}{|c|c|c|c|c|c|c|}
\hline $\begin{array}{l}\text { Drying } \\
\text { method }\end{array}$ & $\begin{array}{c}\text { Drying } \\
\text { condition }\end{array}$ & $\begin{array}{l}{ }^{*} \text { Moisture content } \\
\left(\times 10^{-2} \mathrm{~kg} / \mathrm{kg}, \text { d.b. }\right)\end{array}$ & Hardness $(\mathrm{N})$ & Crispness & Volume ratio & $\begin{array}{c}\text { Rehydration } \\
\text { ratio }\end{array}$ \\
\hline \multirow{3}{*}{$\mathrm{AD}$} & $60^{\circ} \mathrm{C}$ & $8.30 \pm 0.01^{\mathrm{d}}$ & $86.9 \pm 8.1^{\mathrm{d}}$ & $4 \pm 1^{\mathrm{a}}$ & $0.19 \pm 0.00^{\mathrm{a}}$ & $4.56 \pm 0.18^{\mathrm{a}}$ \\
\hline & $75^{\circ} \mathrm{C}$ & $6.50 \pm 0.01^{b c}$ & $43.7 \pm 4.7^{\mathrm{b}}$ & $38 \pm 3^{\mathrm{b}}$ & $0.21 \pm 0.01^{\mathrm{ab}}$ & $4.95 \pm 0.11^{\mathrm{b}}$ \\
\hline & $90^{\circ} \mathrm{C}$ & $5.76 \pm 0.50^{\mathrm{ab}}$ & $43.4 \pm 5.6^{\mathrm{b}}$ & $74 \pm 10^{\mathrm{c}}$ & $0.21 \pm 0.03^{\mathrm{b}}$ & $4.99 \pm 0.10^{\mathrm{b}}$ \\
\hline \multirow{3}{*}{ IR } & $60^{\circ} \mathrm{C}$ & $7.03 \pm 0.11^{c}$ & $57.7 \pm 3.6^{c}$ & $5 \pm 1^{\mathrm{a}}$ & $0.19 \pm 0.00^{\mathrm{a}}$ & $4.82 \pm 0.10^{\mathrm{ab}}$ \\
\hline & $75^{\circ} \mathrm{C}$ & $5.95 \pm 0.13^{\mathrm{abc}}$ & $50.3 \pm 2.5^{\mathrm{bc}}$ & $69 \pm 7^{c}$ & $0.21 \pm 0.03^{\mathrm{ab}}$ & $5.08 \pm 0.13^{\mathrm{b}}$ \\
\hline & $90^{\circ} \mathrm{C}$ & $5.72 \pm 0.21^{\mathrm{ab}}$ & $53.5 \pm 2.0^{\mathrm{bc}}$ & $74 \pm 6^{c}$ & $0.25 \pm 0.01^{\mathrm{ab}}$ & $5.04 \pm 0.18^{\mathrm{b}}$ \\
\hline FD & & $5.29 \pm 0.23^{\mathrm{ab}}$ & $17.4 \pm 1.8^{\mathrm{a}}$ & $10 \pm 3^{\mathrm{a}}$ & $0.76 \pm 0.01^{\mathrm{d}}$ & $7.55 \pm 0.09^{\mathrm{d}}$ \\
\hline DIC & & $5.03 \pm 0.51^{\mathrm{a}}$ & $44.4 \pm 2.3^{\mathrm{bc}}$ & $92 \pm 4^{\mathrm{d}}$ & $0.31 \pm 0.01^{\mathrm{c}}$ & $5.48 \pm 0.35^{\mathrm{c}}$ \\
\hline
\end{tabular}

Results are presented as mean values \pm standard deviation of triplicate tests. Samples in the same column with different letters differ significantly at $p<0.05$. * represents the moisture content of dried apple slices produced by different drying methods.

by the estimation of recovery values [31]. Measurement of neutral sugar compositions was conducted in duplicate.

2.2.10. Molecular Mass Distribution. Molar mass analysis was performed according to the method described by Yang et al. [32]. Dialyzed and lyophilized fraction $(3.0 \mathrm{mg})$ was dissolved in $1 \mathrm{~mL}$ of $0.1 \mathrm{~mol} / \mathrm{L}$ 4-morpholineethanesulfonic acid monohydrate buffer solution (MES), $\mathrm{pH} 6.5$, containing $0.1 \mathrm{~mol} / \mathrm{L} \mathrm{NaCl}$. Molar mass distribution was determined using a high-performance size exclusion chromatography (HPSEC) coupled with multiangle laser light scattering (Malls, Dawn-EOS, Wyatt Tech. Co., Santa Barbara, USA) and refractive index (RI) detector (OptiLab-DSP, Wyatt Tech. Co., Santa Barbara, USA). The abovementioned solution sample $(100 \mu \mathrm{L})$ was injected and separated by a TSK-Gel G3000SW ${ }_{\text {XL }}$ column $(7.8 \mathrm{~mm} \times 300 \mathrm{~mm})$ (Tosoh Co., Tokyo, Japan), eluting with $0.1 \mathrm{~mol} / \mathrm{L}$ MES buffer ( $\mathrm{pH}$ 6.5) containing $0.1 \mathrm{~mol} / \mathrm{L} \mathrm{NaCl}$ at flow rate of $0.45 \mathrm{~mL} / \mathrm{min}$ at $35^{\circ} \mathrm{C}$. RI intensity and light scattering intensity at different angles were used to calculate cell wall polysaccharide concentration and molar mass distribution, respectively [33].

2.2.11. Statistical Analysis. Statistical analysis of the experimental data was conducted by using SPSS Statistics (Version 17.0, SPSS Inc., Chicago, USA), applying one-way analysis of variance (ANOVA) and Duncan's multiple range tests. Significant differences were defined at $p<0.05$.

\section{Results and Discussion}

3.1. Physicochemical Properties. The effects of drying methods and drying temperature on hardness, crispness, water content, volume ratio (VR), and rehydration ratio (RR) of dried apple chips are presented in Table 1. The moisture contents of the samples dried under different conditions ranged from 5.03 to $8.30 \times 10^{-2} \mathrm{~kg} / \mathrm{kg}$ d.b. The hardness of the apple chips was reduced and the crispness was increased as rising of the drying temperature of $\mathrm{AD}$ and IR process; such behavior was reported in few similar studies regarding constant temperature drying of bulbus of Tulipa edulis [34] and air drying of bell pepper [35]. FD dried samples had the minimum value in hardness $(17.4 \mathrm{~N})$ and low crispness (10). Several earlier studies also reported that samples produced using hot air drying were characterized as having higher hardness when compared to freeze drying ([36], Giri et al. 2006). This phenomenon was probably because higher temperature accelerates removal of water from the tissues, but also results in case hardening [37]. Besides, the capillary force which causes water removal and loss of turgor pressure in the cell during HAD resulted in more severe shrinkage than in the process of FD, during which process the material was frozen and the structure became more rigid without collapse [36]. It is worthy to note that the DIC treated apple chips represented the highest crispness value (92) and a modest hardness value $(44.4 \mathrm{~N})$. Conversely, the highest hardness $(86.9 \mathrm{~N})$ and lowest crispness (4) were observed in the treatment of $\mathrm{AD}$ $60^{\circ} \mathrm{C}$. This might be attributed to the hard and dry crust formed in the surface area and the shrinkage of the tissue, due to the rate of inner water transferring to the surface being limited during $\mathrm{AD}$ at $60^{\circ} \mathrm{C}$. The volume ratio (VR) of the samples dried by all the selected drying methods is smaller than 1.0, suggesting that all of the drying processes would lead to shrinkage for apple slices. The VR of the FD dried samples (0.76) was the highest, followed by the DIC finished samples $(0.31)$, and the samples dried by $\mathrm{AD}$ at $60^{\circ} \mathrm{C}$ and IR at $60^{\circ} \mathrm{C}$ had the lowest VR, which were both 0.19 . The highest VR of the FD dried samples may be due to the maintaining of freezing or solid state of the samples throughout the FD process. During FD process, the ice was sublimated in the vacuum and frozen condition; then the homogeneous voids were left within the structure [38]. As expected, the VR of the DIC treated samples was significantly smaller than that of the FD dried samples. However, for the DIC treatment, though the compact structure could be substantially expanded after instant pressure drop, it still cannot compromise the shrinkage that occurred during the stage of hot air predrying (Mounir et al. 2012), because the cellular structure of the materials and the rigid cell wall networks supporting the plant tissue might be irreversibly damaged by the predrying treatment. On the other hand, during the cooling period of DIC treatment, slight shrinkage may occur due to the viscoelastic behavior of the material. 


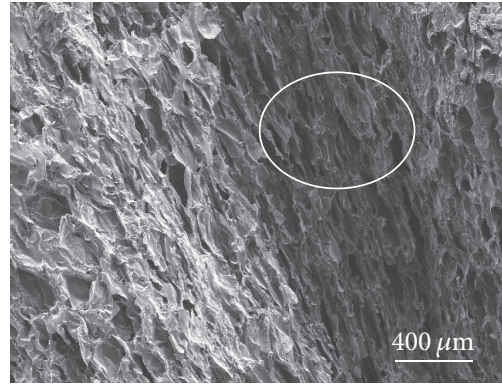

(a)

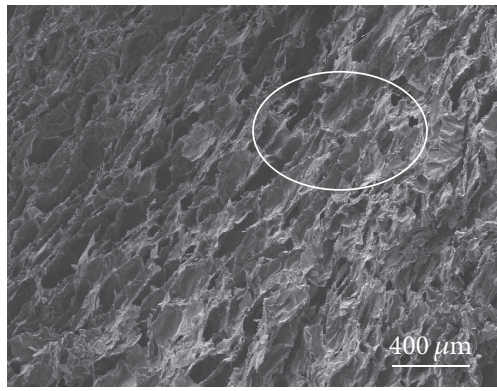

(d)

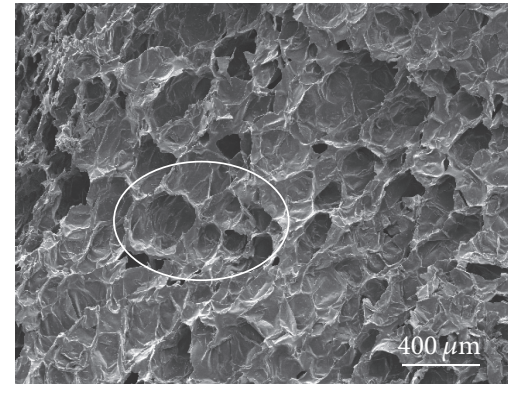

(b)

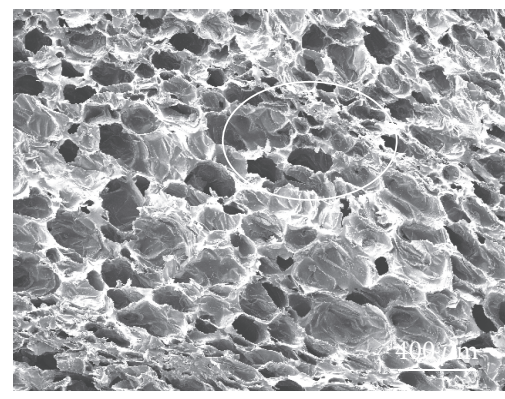

(e)

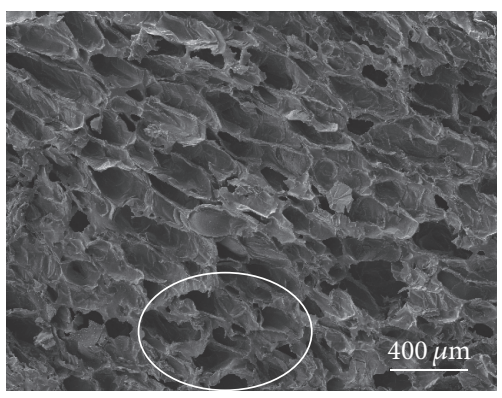

(c)

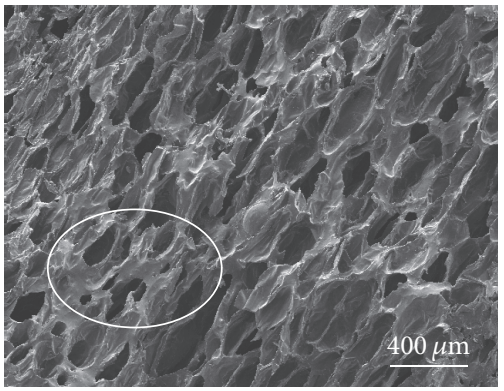

(f)

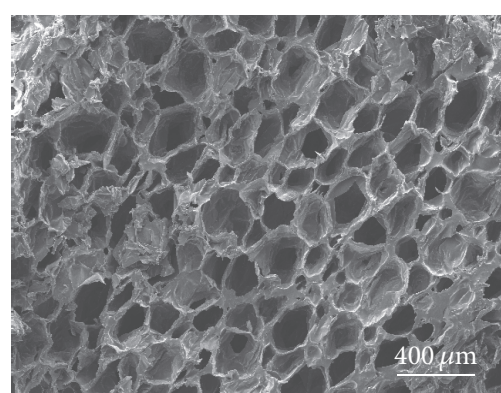

(g)

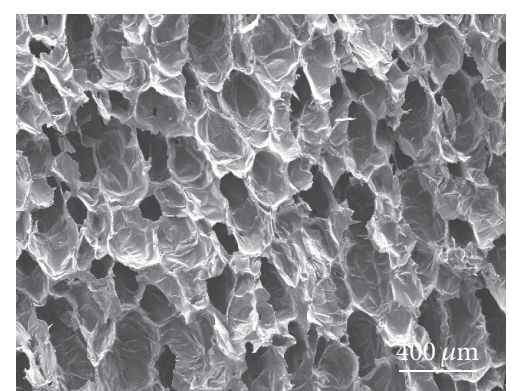

(h)

FIGURE 1: Microstructures of the apple chips dried by hot air drying (AD), medium- and short-wave infrared drying (IR), instant controlled pressure drop drying (DIC), and freeze drying (FD) ( $\times 50)$. (a) $\mathrm{AD} 60^{\circ} \mathrm{C}$, (b) $\mathrm{AD} 75^{\circ} \mathrm{C}$, (c) $\mathrm{AD} 90^{\circ} \mathrm{C}$, (d) $\mathrm{IR} 60^{\circ} \mathrm{C}$, (e) IR $75^{\circ} \mathrm{C}$, (f) IR $90^{\circ} \mathrm{C}$, (g) FD, and (h) DIC. The white circles added in (a), (b), and (c) were used to point the microstructure changes of apple chips, as well as in (d), (e), and (f).

Generally, during the stage of dropping in temperature of DIC drying, the material evolved from high temperaturehigh moisture state towards a low temperature-low moisture state; then, the state of the product could transfer from rubber state to vitreous state [39]; as a result, the new expanded structure can be maintained during the following vacuum drying [40]. Both the VR of the apple chips dried by AD and IR were lower than those of FD and DIC treated samples, and no significant differences in VR were observed between the samples dried by AD and IR at the same temperature. In addition, the VR of the apple chips dried by AD or IR showed an increasing trend with increasing of drying temperature. The smaller shrinkage for apple slices that dried at relatively higher temperature might be ascribed to the fact that apple slices took a shorter time for drying as the temperature and water diffusivity were high [41].

The rehydration ratio (RR) of the FD dried apple chips was 7.55 (Table 1), which was significantly higher than that of the samples dried by the other drying methods, followed by that of DIC samples (5.48). The fact that higher RR was found in the FD and DIC dried samples was due to the homogenous porous structure and big specific surface area of the samples, which allowed a large amount of water molecules to be absorbed during rehydration [42]. The AD and IR dried apple chips showed the minimum of $\mathrm{RR}$, which ranged within 4.56-4.99 and 4.82-5.08, respectively. This could be explained by the hard crust on the outer layer and smaller number of pores inside the samples. Unlike VR, the RR of the samples dried by AD and IR showed a trend that it decreased with increase of the drying temperature.

3.2. Microstructure. The microstructure of dried apples produced by different drying methods was observed by scanning electron microscope to further analyze the texture characteristic of the dried apples chips (Figure 1). There was no pronounced difference between the microstructures of the 
TABLE 2: Effect of drying methods on the galacturonan acid contents of water extractable pectin (WEP), CDTA extractable pectin (CEP), and $\mathrm{Na}_{2} \mathrm{CO}_{3}$ extractable soluble pectin (NEP) of the apple chips obtained by different drying methods.

\begin{tabular}{|c|c|c|c|c|c|}
\hline \multirow{2}{*}{ Drying method } & \multirow{2}{*}{ Drying condition } & \multicolumn{4}{|c|}{ Galacturonan acid (mg/g AIR) } \\
\hline & & WEP & CEP & NEP & Total GalA \\
\hline \multirow{3}{*}{$\mathrm{AD}$} & $60^{\circ} \mathrm{C}$ & $86.9 \pm 2.8^{\mathrm{d}}$ & $41.5 \pm 0.1^{b}$ & $75.0 \pm 6.0^{\mathrm{e}}$ & 203.4 \\
\hline & $75^{\circ} \mathrm{C}$ & $74.6 \pm 1.8^{\mathrm{c}}$ & $40.3 \pm 1.7^{\mathrm{b}}$ & $65.1 \pm 5.2^{\mathrm{d}}$ & 180.0 \\
\hline & $90^{\circ} \mathrm{C}$ & $33.8 \pm 5.8^{\mathrm{a}}$ & $47.3 \pm 4.2^{\mathrm{c}}$ & $45.8 \pm 5.2^{\mathrm{b}}$ & 126.9 \\
\hline \multirow{3}{*}{ IR } & $60^{\circ} \mathrm{C}$ & $85.0 \pm 0.9^{\mathrm{d}}$ & $37.9 \pm 1.2^{\mathrm{ab}}$ & $53.4 \pm 2.0^{\mathrm{bc}}$ & 176.3 \\
\hline & $75^{\circ} \mathrm{C}$ & $75.3 \pm 3.2^{\mathrm{c}}$ & $36.0 \pm 0.1^{\mathrm{ab}}$ & $61.0 \pm 1.6^{\mathrm{cd}}$ & 172.3 \\
\hline & $90^{\circ} \mathrm{C}$ & $65.4 \pm 2.1^{\mathrm{b}}$ & $71.0 \pm 4.2^{\mathrm{e}}$ & $61.5 \pm 3.0^{\mathrm{cd}}$ & 197.9 \\
\hline FD & & $102.7 \pm 1.8^{\mathrm{e}}$ & $38.8 \pm 1.1^{\mathrm{b}}$ & $33.6 \pm 7.3^{\mathrm{a}}$ & 174.4 \\
\hline DIC & & $64.2 \pm 0.8^{\mathrm{b}}$ & $56.1 \pm 2.9^{\mathrm{d}}$ & $51.8 \pm 1.9^{\mathrm{b}}$ & 171.9 \\
\hline Fresh & & $112.7 \pm 0.9^{\mathrm{f}}$ & $32.0 \pm 2.8^{\mathrm{a}}$ & $73.4 \pm 1.4^{\mathrm{e}}$ & 218.1 \\
\hline
\end{tabular}

Results are presented as mean values \pm standard deviation of triplicate tests. Samples in the same column with different letters differ significantly at $p<0.05$.

$\mathrm{AD}$ and IR dried samples at the same drying temperature. As the white circles point in Figures 1(a) and 1(d), among these samples, dense areas were observed in the apple chips dried by $\mathrm{AD}$ at $60^{\circ} \mathrm{C}$ and $\mathrm{IR}$ at $60^{\circ} \mathrm{C}$, revealing significant collapse of tissues after the drying process, thus expecting harder texture and lower RR for these samples. With increasing of the drying temperature for AD (Figures 1(a)-1(c)) and IR (Figures $1(\mathrm{~d})-1(\mathrm{f})$ ) process, typical porous structure was formed apparently, which could be attributed to the enhanced waterremoving rate at the elevated temperature. Moreover, obvious honeycomb-like network and superior porous structure were observed in both the FD and DIC treated samples, pointing to limited shrinkage for the cellular and tissue structure of the apple slices. In addition, it is suggested that the differences in the microstructure of the apples derived from various drying methods could be related to the modification of its chemical constitution and functionality of middle lamella, affecting cellular adhesive properties [43] and thus the texture of the dried apple chips.

3.3. Galacturonic Acid Contents. As GalA is dominant pectic saccharide in the AIR of apple; the amount of GalA found in AIR was estimated to evaluate the amount of pectin in each fraction of AIR. Table 2 summarizes the amount of GalA in different fractions (WEP, CEP, and NEP) of the apple chips dried by various methods. The contents and proportions of WEP, CEP, and NEP varied from drying methods and drying conditions $(p<0.05)$. The contents of the WEP, CEP, and NEP extracted from the fresh apples were $112.7 \mathrm{mg} / \mathrm{g}$ AIR, $32.0 \mathrm{mg} / \mathrm{g}$ AIR, and $73.4 \mathrm{mg} / \mathrm{g}$ AIR, respectively. The contents of the total GalA and WEP of the dried samples (126.9-203.4 mg/g AIR, 33.8-102.7 mg/g AIR) were lower than those of the fresh samples $(218.1 \mathrm{mg} / \mathrm{g}$ AIR, $112.7 \mathrm{mg} / \mathrm{g}$ AIR), while the amount of the CEP fraction was higher. The deviation in total GalA might be partially due to the conversion among different fractions of pectin during the different drying process. In addition, it is supposed that the ratio or efficiency of pectin extraction could be affected by the differences of the microstructure of the apple chips, illustrated above (Figure 1).
The amount of WEP for AD and IR dried samples decreased with increasing of drying temperature, while the CEP contents increased. This might be explained by the fact that leaching of WEP occurred with certain amount of fluid flowing out of the tissue during the drying process or partially converted into CEP fraction. The amount of WEP of the apple chips dried by $\mathrm{AD}$ at $90^{\circ} \mathrm{C}$, IR at $90^{\circ} \mathrm{C}$, and DIC significantly decreased compared with the fresh samples. This was consistent with the result that degradation of WSP and leaching occurred in the drying process with high temperature [44]. The decrease of cell wall macromolecules, for example, pectic polysaccharides, might lead to decrease in $T_{g}$ of the matrix [45]. For the DIC treated sample, the drying temperature was higher than $T_{g}$; therefore, the apple slices entered a viscoelastic state (Welti-Chanes et al. 1999) during the equilibrium process. Due to the high viscoelasticity and plasticity, porous structure was formed when instant pressure drop treatment was introduced. With the moisture content decreased, the products changed from rubbery state to glassy state [39], contributing to the preservation of the expanding and porous structure, thus resulting in superior porous microstructure. In addition, relatively low amount of WEP was found in the DIC treated sample, implying that limited amount of soluble pectin existed for this sample. This could be in favor of cell separation during expansion [46]. The FD dried apple chips exhibited the highest content of WEP fraction $(102.7 \mathrm{mg} / \mathrm{g}$ AIR) among the selected drying methods. The apple slices were quickly frozen before sublimation, and the matrix stayed in frozen or solid state throughout the FD process. Consequently, the leaching of WEP was avoided during the FD process, and the WEP fraction was well retained, whose amount is comparable to the fresh samples. The relatively high amount of WEP in the FD dried sample might partially contribute to the low mechanical strength and the minimum hardness of the products. This may be due to the fact that the WEP is generally made up of high esterified pectic polymers, loosely bound to the cell wall through noncovalent and nonionic bonds, and it could be one of the explanations that FD apple chips presented the highest rehydration ratio [30]. 
TABLE 3: Effect of drying methods on the degree of methoxylation of water extractable pectin (WEP), CDTA extractable pectin (CEP), and $\mathrm{Na}_{2} \mathrm{CO}_{3}$ extractable pectin (NEP) from dehydrated apple chips obtained by different drying methods.

\begin{tabular}{|c|c|c|c|c|}
\hline \multirow{2}{*}{ Drying method } & \multirow{2}{*}{ Drying condition } & \multicolumn{3}{|c|}{ Degree of methoxylation (\%) } \\
\hline & & WEP & CEP & NEP \\
\hline \multirow{3}{*}{$\mathrm{AD}$} & $60^{\circ} \mathrm{C}$ & $59.7 \pm 3.2^{\mathrm{a}}$ & $37.6 \pm 3.6^{\mathrm{bcd}}$ & $1.3 \pm 0.0^{\mathrm{bcd}}$ \\
\hline & $75^{\circ} \mathrm{C}$ & $60.5 \pm 0.7^{\mathrm{ab}}$ & $34.6 \pm 0.1^{\mathrm{bc}}$ & $1.2 \pm 0.3^{\mathrm{bc}}$ \\
\hline & $90^{\circ} \mathrm{C}$ & $71.8 \pm 0.7^{\mathrm{cd}}$ & $24.86 \pm 1.2^{\mathrm{a}}$ & $0.7 \pm 0.0^{\mathrm{ab}}$ \\
\hline \multirow{3}{*}{ IR } & $60^{\circ} \mathrm{C}$ & $66.2 \pm 1.8^{\mathrm{bc}}$ & $43.4 \pm 0.9^{\mathrm{d}}$ & $2.0 \pm 0.1^{\mathrm{de}}$ \\
\hline & $75^{\circ} \mathrm{C}$ & $72.4 \pm 1.8^{\mathrm{cd}}$ & $40.2 \pm 1.2^{\mathrm{cd}}$ & $0.9 \pm 0.1^{\mathrm{b}}$ \\
\hline & $90^{\circ} \mathrm{C}$ & $73.2 \pm 6.2^{\mathrm{d}}$ & $17.5 \pm 5.1^{\mathrm{a}}$ & $0.1 \pm 0.0^{\mathrm{a}}$ \\
\hline FD & & $80.8 \pm 0.7^{\mathrm{e}}$ & $33.8 \pm 0.1^{\mathrm{bc}}$ & $5.0 \pm 0.8^{\mathrm{f}}$ \\
\hline DIC & & $77.5 \pm 2.0^{\mathrm{f}}$ & $23.3 \pm 0.4^{\mathrm{a}}$ & $2.3 \pm 0.2^{\mathrm{d}}$ \\
\hline Fresh & & $69.8 \pm 0.6^{\mathrm{cd}}$ & $36.4 \pm 5.8^{\mathrm{bcd}}$ & $1.7 \pm 0.3^{\text {cde }}$ \\
\hline
\end{tabular}

Results are presented as mean values \pm standard deviation of triplicate tests. Samples in the same column with different letters differ significantly at $p<0.05$.

3.4. Degree of Methoxylation. The DM of pectin, a key functional parameter, was estimated as the ratio of the molar amount of methanol groups to the molar amount of GalA. The DM affects the hydrogen bonding between pectin molecular interactions and might also influence the texture of dried fruits and vegetable. The DM of the WEP, CEP, and NEP fractions are represented in Table 3. Generally, the DM of the WEP fraction was the highest $(59.7 \%-80.8 \%)$, followed by the CEP fraction $(17.5 \%-43.4 \%)$ and NEP fraction $(0.1 \%-5.0 \%)$. This observation was corresponding to the fact that the NEP was extracted from the AIR using aqueous $\mathrm{Na}_{2} \mathrm{CO}_{3}$, a reagent that broke various types of ester linkages [47]. It was found that the DM of the WEP fraction increased with increasing of the temperature for $\mathrm{AD}$ and IR. This might be ascribed to the inactivation of pectin methylesterase at higher temperature; thus de-esterification was limited at drying temperature of $75^{\circ} \mathrm{C}$ and $90^{\circ} \mathrm{C}$ compared with drying at $60^{\circ} \mathrm{C}$. On the contrary, the DM of the CEP fractions displayed an opposite trend. It could be due to the consequence of deesterification of the WEP fraction, which might be partially cross-linked with free divalent ionic and thus transferred to CEP factions. In addition, CEP fractions with low DE would contain more carboxyl groups, with higher amount of crosslinking with metal ions such as $\mathrm{Ca}^{2+}$ [48], and such effects could contribute to the rigidity of the microstructure of apple chips. This could be a partial explanation for the fact that the crispness of the apple chips obtained by $\mathrm{AD}$ at $90^{\circ} \mathrm{C}$, IR at $90^{\circ} \mathrm{C}$, and DIC was higher than that by the other drying methods, and vice versa for the hardness.

3.5. Sugar Ratio. Pectin is a kind of cell wall polysaccharide that mainly consists of a linear chain of covalently linked galacturonic acid. Various amounts of neutral sugars are attached to these regions as side chains, including fucose, rhamnose, arabinose, galactose, and xylose. Based on the amount and linkage types of side chains, pectin is generally described as homogalacturonan (HG), rhamnogalacturonanI (RG-I), and rhamnogalacturonan-II (RG-II) [10]. In general, HG is composed of a linear chain of $(1,4)$-linked- $D$ galacturonic acid. RG-I consists of repeats of disaccharide $(1,2)-\alpha$ - $L$-rhamnose- $(1,4)-\alpha$ - $D$-galacturonic acid. RG-II is a branched pectic domain containing an HG backbone. The use of "sugar ratios" can help to interpret the sugar information on the polymeric level. Sugar ratios 1, 2, and 3 are formulated specifically for pectin, assuming a linear pectin structure, in which the backbones of RG-I and RG-II are continuous with the linear HG structure [49]. As shown in Table 4, the amount of GalA to neutral sugars in side chains (sugar ratio 1) can be an indication for the linearity of pectin; sugar ratio 2 is embodied by the ratio of Rha to GalA, a measurement for the contribution of RG to the entire pectin population. The proportion of RG-I side-chain sugars to Rha (sugar ratio 3) is indicative for the extent of branching of RG-I [15]. The linearity of the WEP and CEP fractions of the fresh samples was 13.62 and 26.63, respectively. The linearity of the WEP of the dried apple slices was lower than that of the fresh samples, and the opposite was found in the CEP fractions. Meanwhile, in the case of $\mathrm{AD}$ and IR dried samples, the linearity of the WEP decreased with increasing of the temperature, while CEP showed the opposite trend, implying fraction on the WEP backbone and side chain of the CEP fractions. In addition, based on the fact that the amount of WEP fraction was reduced after drying, it is speculated that significant degradation of the pectic polysaccharides occurred during drying process, and these residues with small molecular mass might not be included in the WEP fraction after extraction process. It can be observed that the sugar ratio 2 of the WEP, CEP, and NEP fraction from all of the samples was small, ranging from 0.01 to 0.04 , indicating that the proportion of RG is small for apple pectic polysaccharides. The WEP exhibited the highest extent of RG-I branching (sugar ratio 3) among all the pectic fractions, ranging from 6.87 to 10.31 , indicating that the WEP fractions were loosely bound to the cell wall and thus were extracted by a relatively moderate condition.

3.6. Molar Mass Distribution. Figure 2 illustrates the molar mass distribution and concentration profiles of the cell wall polysaccharides in the WEP fractions of the apple chips. The molar mass distributions of the cell wall polysaccharides extracted from different samples were similar for all the WEP fractions of different samples. The MALLS and RI signals 
TABLE 4: Effect of drying methods on sugar ratios of water extractable pectin (WEP), CDTA extractable pectin $(\mathrm{CEP})$, and $\mathrm{Na}_{2} \mathrm{CO}_{3}$ extractable pectin (NEP) from dehydrated apple chips obtained by different drying methods.

\begin{tabular}{|c|c|c|c|c|c|c|c|c|c|c|}
\hline & \multirow{2}{*}{ Sugar ratio } & \multicolumn{3}{|c|}{$\mathrm{AD}$} & \multicolumn{3}{|c|}{ IR } & \multirow{2}{*}{$\mathrm{FD}$} & \multirow{2}{*}{ DIC } & \multirow{2}{*}{ Fresh } \\
\hline & & $60^{\circ} \mathrm{C}$ & $75^{\circ} \mathrm{C}$ & $90^{\circ} \mathrm{C}$ & $60^{\circ} \mathrm{C}$ & $75^{\circ} \mathrm{C}$ & $90^{\circ} \mathrm{C}$ & & & \\
\hline \multirow{3}{*}{ WEP } & 1 & 11.83 & 10.35 & 6.05 & 12.35 & 9.24 & 7.02 & 7.19 & 5.64 & 13.62 \\
\hline & 2 & 0.01 & 0.01 & 0.01 & 0.01 & 0.01 & 0.01 & 0.02 & 0.02 & 0.01 \\
\hline & 3 & 10.31 & 8.50 & 9.78 & 9.05 & 8.79 & 9.80 & 6.87 & 6.92 & 7.18 \\
\hline \multirow{3}{*}{ CEP } & 1 & 37.05 & 35.02 & 44.27 & 30.76 & 31.27 & 49.42 & 27.03 & 33.55 & 26.63 \\
\hline & 2 & 0.00 & 0.01 & 0.00 & 0.00 & 0.01 & 0.00 & 0.01 & 0.00 & 0.01 \\
\hline & 3 & 5.61 & 4.42 & 5.90 & 5.62 & 4.28 & 4.31 & 4.21 & 3.98 & 5.12 \\
\hline \multirow{3}{*}{ NEP } & 1 & 13.54 & 8.67 & 6.04 & 10.78 & 9.86 & 6.76 & 3.79 & 6.56 & 5.65 \\
\hline & 2 & 0.01 & 0.02 & 0.02 & 0.01 & 0.01 & 0.02 & 0.04 & 0.03 & 0.03 \\
\hline & 3 & 3.84 & 3.88 & 4.90 & 3.35 & 4.87 & 4.97 & 3.74 & 3.21 & 4.65 \\
\hline
\end{tabular}

Note. Sugar ratio $1=\mathrm{GalA} /(\mathrm{Fuc}+\mathrm{Rha}+\mathrm{Ara}+\mathrm{Xyl})$, representing the linearity of pectin; sugar ratio $2=\mathrm{Rha} / \mathrm{Gala}$, representing the contribution of RG to pectin population; sugar ratio $3=(\mathrm{Ara}+\mathrm{Gal}) / \mathrm{Rha}$, representing the branching of RG-I [15].

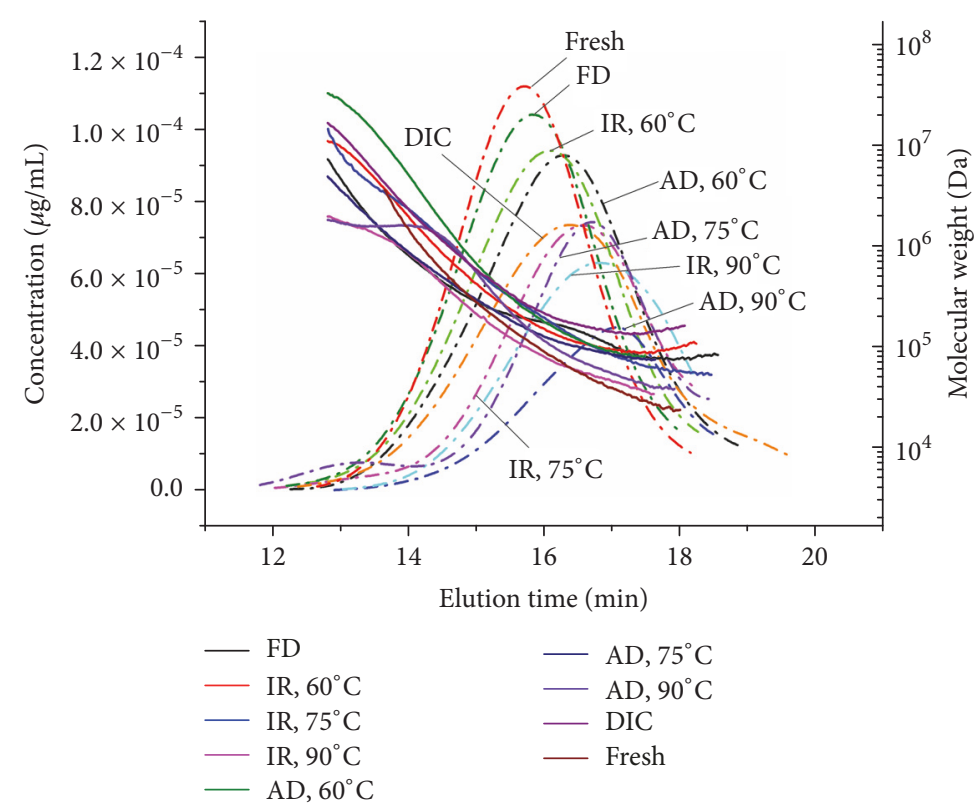

FIGURE 2: Molar mass distribution of the water extractable pectins of the apple chips dried by hot air drying (AD), medium- and short-wave infrared drying (IR), instant controlled pressure drop drying (DIC), and vacuum freeze drying (FD). Solid lines indicate molecular weight of the WEP fraction, and dash-dotted lines indicate the concentration of the WEP fraction.

of CEP fractions were low; thus the data were not shown. The elution times of the WEP fractions of the fresh samples and FD dried chips (around 15.5-15.7 min) were generally shorter than those of the AD, IR, and DIC dried samples, suggesting that the molar mass of WEP fraction from fresh and FD dried samples was higher than that from other samples. The data corroborated that limited degradation and de-esterification occurred during FD drying process, which contributed to its higher amount of water extractable pectic polysaccharides with high DM (Tables 2 and 3). Interestingly, peak shifting to longer elution times in the WEP fractions was observed with increasing of the drying temperature for $\mathrm{AD}$ and IR process, together with the apparent decrease in the concentrations of the samples. It implied that the extent of cell wall polysaccharide degradation was raised correspondingly. Moreover, the elution times of the peaks for $\mathrm{AD}$ dried products were generally longer than those of the IR dried chips at the same drying temperature. The corresponding concentrations of the AD dried products were generally lower than those of the IR dried products, which was consistent with the results of the amounts of WEP fraction (Table 2). This phenomenon might be attributed to the longer drying time for the $\mathrm{AD}$ process compared with IR process when performed at the same drying temperature. For the DIC treated apple chips, significant decrease in molar mass was also found.

The modifications in cell wall polysaccharides could affect the physicochemical and physical properties of the apple 
chips. Firstly, the occurrence of polysaccharide depolymerization and the modification of cell wall polysaccharide intermolecular interactions (Table 2) suggested that cell wall polysaccharide network might be disorganized and misaligned to certain extent due to the drying process. This might damage the integrity of the primary cell wall and/or middle lamella of apple slices, leading to the decrease in the strength of intercellular adhesion. Consequently, the reduction in intercellular adhesion strength might be in favor of tissue/cell separation and reduce the internal structural resistance for volume expansion during instant pressure drop treatment or $\mathrm{AD}$ and IR drying at elevated temperature, that is, $90^{\circ} \mathrm{C}$. This, consequently, could contribute to a more porous microstructure as well as a crispier texture for the apple chips. Secondly, polysaccharide degradation could provide higher amounts of pectic residues with smaller molecular mass, leading to a better hydrophilicity for cell wall polysaccharides, which was a partial explanation for the improvement of rehydration rate and capacity. This was in good agreement with the report of Latorre et al. [12], who found that the modification of cell wall polysaccharide structure induced by microwave drying led to a significant increase in the hydrophilicity of cell wall polysaccharide. In addition, the superior porous microstructure in the DIC treated samples, as well as the AD and IR $\left(90^{\circ} \mathrm{C}\right)$ dried sample, could facilitate a faster capillary suction during immersing, which was another reason for their superior rehydration properties (Table 1). On the other hand, cell wall polysaccharide depolymerization produced chemical residues with smaller molecular mass, which could increase the molecular mobility of a system, thus decreasing the glass transition point $\left(T_{q}\right)$ of the matrix. Moreover, the damage and misalignment of cell wall polysaccharide network might liberate part of structural polysaccharides from cell wall, which could also increase molecular mobility and contribute to decreasing $T_{g}$, and these effects might bring adverse effects for volume expansion. Overall, data from the results of the texture and microstructure (Table 1 and Figure 1), as well as the amount of pectic fractions, DM, and the sugar ratios (Tables 2, 3, and 4) suggested that the modifications of cell wall polysaccharides induced by the drying process significantly contributed to the final texture of apple chips.

\section{Conclusions}

Apple chips were produced by AD, IR, FD, and DIC, respectively. The influences of the modification in the extractability, composition, and structure of cell wall polysaccharide induced by various drying processes on the volume expansion, microstructure, rehydration behavior, and so on suggested that cell wall polysaccharides modification played a significant role in the texture properties of the apple chips. The amounts and structural properties of the WEP and CEP fractions obviously related to the texture properties of the dried samples. Based on the data, the apple chips exhibited higher crispness and better microstructure when there was less amount of WEP fraction, which might be partially attributed to depolymerization and leaching of the pectic polysaccharides. Cell wall polysaccharide degradation was in favor of volume expansion during instant pressure drop treatment, as well as $\mathrm{AD}$ and IR drying at elevated temperatures, consequently, contributing to a superior porous structure and crispier texture. Since cell wall polysaccharides are a nonnegligible factor affecting the formation and hardening of the porous structure for dried products, the influences of cell wall polysaccharide modification during different stages of drying process, for example, pretreatment, predrying, DIC, and final drying, on texture evolution can be better understood by further study using model system.

\section{Additional Points}

Practical Applications. Nowadays, a rapid increase in the fruit and vegetable chips is witnessed because of their health benefits. Instant controlled pressure drop drying (DIC) is one of the available industrial technologies for producing fruit and vegetable chips. Currently, apple chips are the main products in the Chinese market due to their crispy texture and pleasant flavor. However, the texture of apple chips is unstable during industrial manufacturing due to limited information about the fundamentals of texture evolution, which, except for the final microstructure and moisture content, is supposed to be related to pectic polysaccharides. Therefore, better understanding of the relationship between the texture of apple chips and the modification of pectic polysaccharides could be helpful to guarantee excellent crispy texture of the products.

\section{Conflicts of Interest}

The authors declare that they have no conflicts of interest.

\section{Acknowledgments}

The authors acknowledge the National Key R\&D Program of China (2016YFD0400700 and 2016YFD0400704).

\section{References}

[1] D. A. Hyson, "A comprehensive review of apples and apple components and their relationship to human health," Advances in Nutrition, vol. 2, no. 5, pp. 408-420, 2011.

[2] M. U. Joardder, A. Karim, C. Kumar, and R. J. Brown, "Effect of cell wall properties of plant tissue on porosity and shrinkage during drying," in 1st International Conference on Food Properties, Kuala Lumpur, Malaysia, 2014.

[3] J.-Y. Yi, L.-Y. Zhou, J.-F. Bi, P. Wang, X. Liu, and X.-Y. Wu, "Influence of number of puffing times on physicochemical, color, texture, and microstructure of explosion puffing dried apple chips," Drying Technology, vol. 34, no. 7, pp. 773-782, 2016.

[4] A. Vega-Gálvez, L. Zura-Bravo, R. Lemus-Mondaca et al., "Influence of drying temperature on dietary fibre, rehydration properties, texture and microstructure of Cape gooseberry (Physalis peruviana L.)," Journal of Food Science and Technology, vol. 52, no. 4, pp. 2304-2311, 2015.

[5] M. Akbarian, B. Ghanbarzadeh, M. Sowti, and J. Dehghannya, "Effects of pectin-CMC-based coating and osmotic dehydration pretreatments on microstructure and texture of the hot-air 
dried quince slices," Journal of Food Processing and Preservation, vol. 39, no. 3, pp. 260-269, 2015.

[6] V. Singh, N. Guizani, A. Al-Alawi, M. Claereboudt, and M. S. Rahman, "Instrumental texture profile analysis (TPA) of date fruits as a function of its physico-chemical properties," Industrial Crops and Products, vol. 50, pp. 866-873, 2013.

[7] D. J. Karakurt, "Cell wall-degrading enzymes and pectin solubility and depolymerization in immature and ripe watermelon (Citrullus lanatus) fruit in response to exogenous ethylene," Physiologia Plantarum, vol. 116, no. 3, pp. 398-405, 2002.

[8] D. N. Sila, T. Duvetter, A. De Roeck et al., "Texture changes of processed fruits and vegetables: potential use of high-pressure processing," Trends in Food Science \& Technology, vol. 19, no. 6, pp. 309-319, 2008.

[9] J. P. Moore, J. M. Farrant, and A. Driouich, "A role for pectin-associated arabinans in maintaining the flexibility of the plant cell wall during water deficit stress," Plant Signaling and Behavior, vol. 3, no. 2, pp. 102-104, 2008.

[10] D. N. Sila, S. Van Buggenhout, T. Duvetter et al., "Pectins in processed fruits and vegetables: part II-structure-function relationships," Comprehensive Reviews in Food Science and Food Safety, vol. 8, no. 2, pp. 86-104, 2009.

[11] A. Femenia, M. J. Bestard, N. Sanjuan, C. Rosselló, and A. Mulet, "Effect of rehydration temperature on the cell wall components of broccoli (Brassica oleracea L. Var. italica) plant tissues," Journal of Food Engineering, vol. 46, no. 3, pp. 157-163, 2000.

[12] M. E. Latorre, M. F. de Escalada Plá, A. M. Rojas, and L. N. Gerschenson, "Blanching of red beet (Beta vulgaris L. var. conditiva) root. Effect of hot water or microwave radiation on cell wall characteristics," LWT-Food Science and Technology, vol. 50, no. 1, pp. 193-203, 2013.

[13] J. Yi, L. Zhou, J. Bi, Q. Chen, X. Liu, and X. Wu, "Impacts of pre-drying methods on physicochemical characteristics, color, texture, volume ratio, microstructure and rehydration of explosion puffing dried pear chips," Journal of Food Processing and Preservation, vol. 40, no. 5, pp. 863-873, 2016.

[14] M. A. Asgar, R. Yamauchi, and K. Kato, "Structural features of pectins from fresh and sun-dried Japanese persimmon fruit," Food Chemistry, vol. 87, no. 2, pp. 247-251, 2004.

[15] K. Houben, R. P. Jolie, I. Fraeye, A. M. Van Loey, and M. E. Hendrickx, "Comparative study of the cell wall composition of broccoli, carrot, and tomato: structural characterization of the extractable pectins and hemicelluloses," Carbohydrate Research, vol. 346, no. 9, pp. 1105-1111, 2011.

[16] Z.-W. Cui, C.-Y. Li, C.-F. Song, and Y. Song, "Combined microwave-vacuum and freeze drying of carrot and apple chips," Drying Technology, vol. 26, no. 12, pp. 1517-1523, 2008.

[17] J.-F. Bi, X. Wang, Q.-Q. Chen et al., "Evaluation indicators of explosion puffing Fuji apple chips quality from different Chinese origins," LWT- Food Science and Technology, vol. 60, no. 2, pp. 1129-1135, 2015.

[18] L. B. H. Said, S. Bellagha, and K. Allaf, "Measurements of texture, sorption isotherms and drying/rehydration kinetics of dehydrofrozen-textured apple," Journal of Food Engineering, vol. 165, pp. 22-33, 2015.

[19] K. Zou, J. Teng, L. Huang, X. Dai, and B. Wei, "Effect of osmotic pretreatment on quality of mango chips by explosion puffing drying," LWT_Food Science and Technology, vol. 51, no. 1, pp. 253-259, 2013.
[20] K. Rungthip, D. Sakamon, and C. Naphaporn, "Effect of starch retrogradation on texture of potato chips produced by lowpressure superheated steam drying," Journal of Food Engineering, vol. 89, no. 1, pp. 72-79, 2008.

[21] A. Nath and P. K. Chattopadhyay, "Effect of process parameters and soy flour concentration on quality attributes and microstructural changes in ready-to-eat potato-soy snack using high-temperature short time air puffing," LWT-Food Science and Technology, vol. 41, no. 4, pp. 707-715, 2008.

[22] L. Seremet, E. Botez, O.-V. Nistor, D. G. Andronoiu, and G.-D. Mocanu, "Effect of different drying methods on moisture ratio and rehydration of pumpkin slices," Food Chemistry, vol. 195, pp. 104-109, 2016.

[23] S. G. Gwanpua, S. Van Buggenhout, B. E. Verlinden et al., "Pectin modifications and the role of pectin-degrading enzymes during postharvest softening of Jonagold apples," Food Chemistry, vol. 158, pp. 283-291, 2014.

[24] S. Christiaens, S. Van Buggenhout, K. Houben, D. Chaula, A. M. Van Loey, and M. E. Hendrickx, "Unravelling process-induced pectin changes in the tomato cell wall: an integrated approach," Food Chemistry, vol. 132, no. 3, pp. 1534-1543, 2012.

[25] T. Stolle-Smits, J. G. Beekhuizen, K. Recourt, A. G. J. Voragen, and C. Van Dijk, "Changes in pectic and hemicellulosic polymers of green beans (Phaseolus vulgaris L.) during industrial processing," Journal of Agricultural and Food Chemistry, vol. 45, no. 12, pp. 4790-4799, 1997.

[26] A. E. R. Ahmed and J. M. Labavitch, "A simplified method for accurate determination of cell wall uronide content," Journal of Food Biochemistry, vol. 1, pp. 361-365, 2010.

[27] N. Blumenkrantz and G. Asboe-Hansen, "New method for quantitative determination of uronic acids," Analytical Biochemistry, vol. 54, no. 2, pp. 484-489, 1973.

[28] A. Ng and K. W. Waldron, "Effect of cooking and pre-cooking on cell-wall chemistry in relation to firmness of carrot tissues," Journal of the Science of Food and Agriculture, vol. 73, no. 4, pp. 503-512, 1997.

[29] J. A. Klavons and R. D. Bennett, "Determination of methanol using alcohol oxidase and its application to methyl ester content of pectins," Journal of Agricultural and Food Chemistry, vol. 34, no. 4, pp. 597-599, 1986.

[30] D. M. Njoroge, P. K. Kinyanjui, A. O. Makokha et al., "Extraction and characterization of pectic polysaccharides from easyand hard-to-cook common beans (Phaseolus vulgaris)," Food Research International, vol. 64, pp. 314-322, 2014.

[31] A. Arnous and A. S. Meyer, "Comparison of methods for compositional characterization of grape (Vitis vinifera L.) and apple (Malus domestica) skins," Food and Bioproducts Processing, vol. 86, no. 2, pp. 79-86, 2008.

[32] C. Yang, Y. Gou, J. Chen, J. An, W. Chen, and F. Hu, "Structural characterization and antitumor activity of a pectic polysaccharide from Codonopsis pilosula," Carbohydrate Polymers, vol. 98, no. 1, pp. 886-895, 2013.

[33] L. C. Vriesmann, R. F. Teófilo, and C. L. D. O. Petkowicz, "Optimization of nitric acid-mediated extraction of pectin from cacao pod husks (Theobroma cacao L.) using response surface methodology," Carbohydrate Polymers, vol. 84, no. 4, pp. 12301236, 2011.

[34] X.-H. Yang, Q.-S. Guo, Z.-B. Zhu et al., "Effects of different drying methods on processing performance and quality in bulbus of Tulipa edulis," Journal of Chinese Meteria Medica, vol. 40, no. 20, pp. 3974-3980, 2015. 
[35] Oduneye, "Effects of drying methods on rehydration and textural properties of bell pepper (capsicum annuum)," Tech. Rep., 2014.

[36] G. Rajkumar, S. Shanmugam, M. D. S. Galvâo et al., "Comparative evaluation of physical properties and volatiles profile of cabbages subjected to hot air and freeze drying," Drying Technology, vol. 35, no. 6, pp. 699-708, 2017.

[37] S. K. Giri, "Quality and sorption characteristics of microwavevacuum, air and freeze dried button mushrooms," in ASABE Annual International Meeting, 066206, Portland, Ore, USA, 2006.

[38] B. Koc, İ. Eren, and F. K. Ertekin, "Modelling bulk density, porosity and shrinkage of quince during drying: the effect of drying method," Journal of Food Engineering, vol. 85, no. 3, pp. 340-349, 2008.

[39] S. Mounir, C. Besombes, N. Al-Bitar, and K. Allaf, "Study of instant controlled pressure drop DIC treatment in manufacturing snack and expanded granule powder of Apple and Onion," Drying Technology, vol. 29, no. 3, pp. 331-341, 2011.

[40] D. Turnbull and M. H. Cohen, "Free-volume model of the amorphous phase: glass transition," The Journal of Chemical Physics, vol. 34, no. 1, pp. 120-125, 1961.

[41] M. Maskan, "Drying, shrinkage and rehydration characteristics of kiwifruits during hot air and microwave drying," Journal of Food Engineering, vol. 48, no. 2, pp. 177-182, 2001.

[42] S. Parthasarathi and C. Anandharamakrishnan, "Modeling of shrinkage, rehydration and textural changes for food structural analysis: a review," Journal of Food Process Engineering, vol. 37, no. 2, pp. 199-210, 2014.

[43] V. Marsilio, B. Lanza, C. Campestre, and M. De Angelis, "Oven-dried table olives: textural properties as related to pectic composition," Journal of the Science of Food and Agriculture, vol. 80, no. 8, pp. 1271-1276, 2000.

[44] J. Lyu, Quality evaluation of peach chips and anticancer activity of pectin extracted from chips dehydrated by explosion puffing drying, Université de Liège, Liège, Belgique, 2017.

[45] V. N. Novikov and E. A. Rössler, "Similar dependence of glass transition temperature on molecular mass in molecular glasses and polymers," in International Conference on Times of Polymers \& Composites, vol. 1599, pp. 130-133, American Institute of Physics, 2014.

[46] D. N. Sila, C. Smout, F. Elliot, A. Van Loey, and M. Hendrickx, "Non-enzymatic depolymerization of carrot pectin: toward a better understanding of carrot texture during thermal processing," Journal of Food Science, vol. 71, no. 1, pp. E1-E9, 2010.

[47] R. R. Selvendran and M. A. O'Neill, "Isolation and analysis of cell walls from plant material," Methods of Biochemical Analysis, vol. 32, pp. 25-153, 1987.

[48] M.-C. Ralet, M.-J. Crépeau, H.-C. Buchholt, and J.-F. Thibault, "Polyelectrolyte behaviour and calcium binding properties of sugar beet pectins differing in their degrees of methylation and acetylation," Biochemical Engineering Journal, vol. 16, no. 2, pp. 191-201, 2003.

[49] K. H. Caffall and D. Mohnen, "The structure, function, and biosynthesis of plant cell wall pectic polysaccharides," Carbohydrate Research, vol. 344, no. 14, pp. 1879-1900, 2009. 


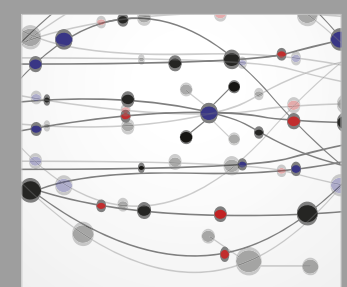

The Scientific World Journal
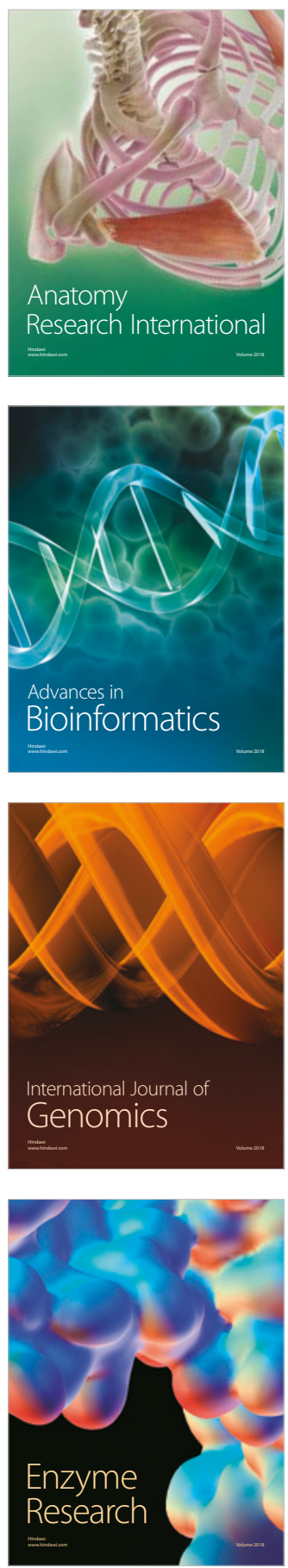
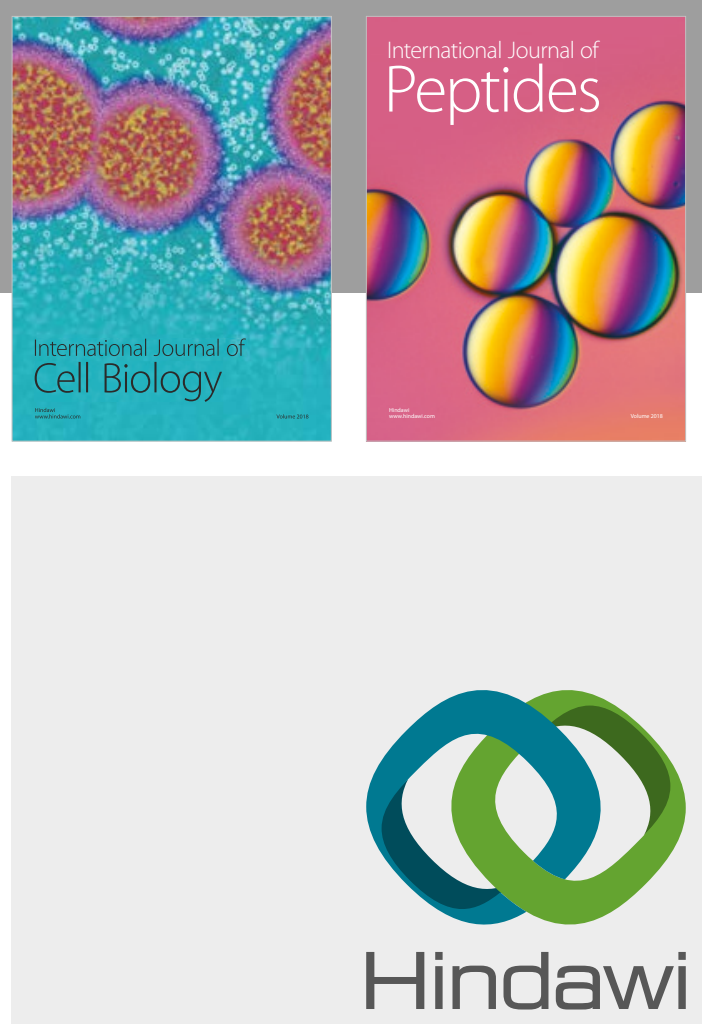

Submit your manuscripts at

www.hindawi.com
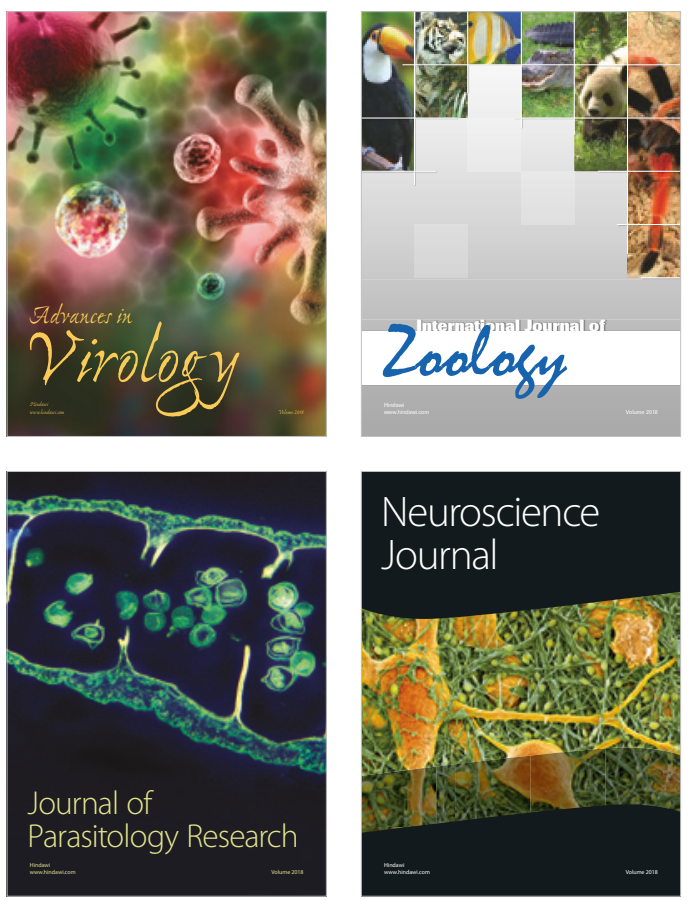
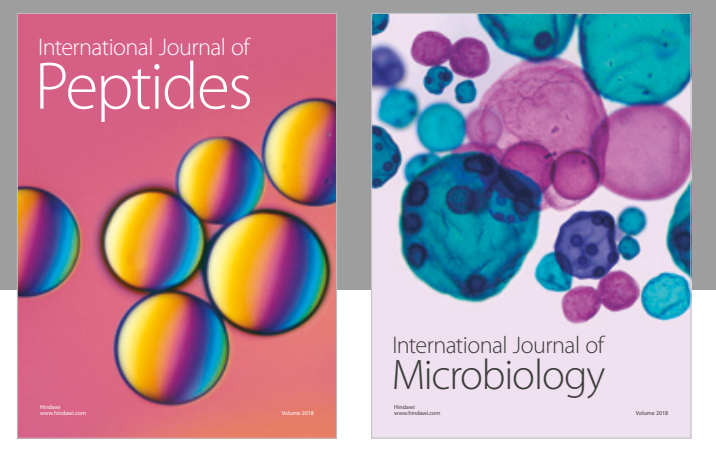

nternational Journal of Microbiology
Journal of
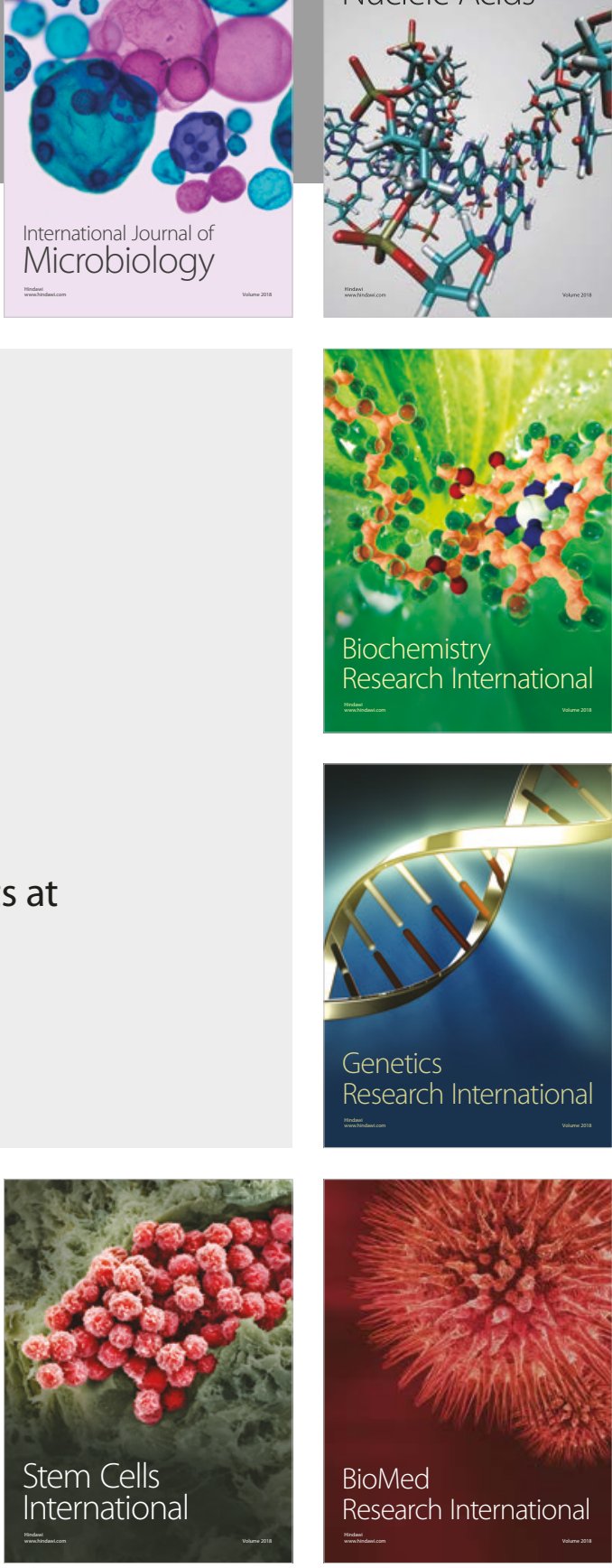
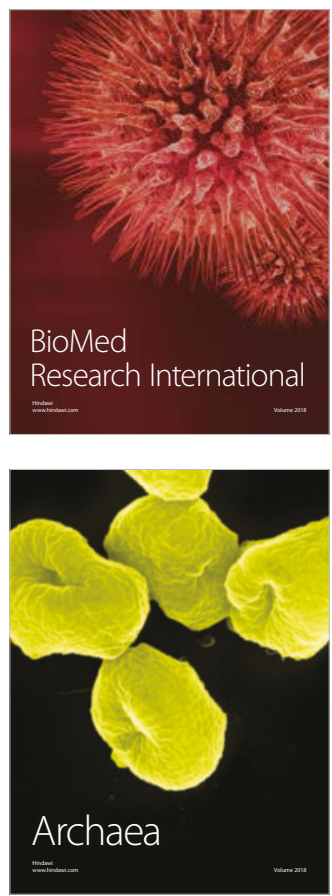